\section{B A Institute of \\ YK Business Administration \\ 六下 \\ Karachi \\ Leadership and Ideas for Tomorrow}

Business Review

Volume 6 Issue 2 July-December 2011

$7-1-2011$

\title{
Financial development and firms' growth in textile industry of Pakistan: A panel data analysis
}

ljaz Hussain

Beaconhouse National University, Lahore, Pakistan

Follow this and additional works at: https://ir.iba.edu.pk/businessreview

Part of the Finance and Financial Management Commons, and the Growth and Development Commons

(c) (1)

This work is licensed under a Creative Commons Attribution 4.0 International License.

\section{Recommended Citation}

Hussain, I. (2011). Financial development and firms' growth in textile industry of Pakistan: A panel data analysis. Business Review, 6(2), 97-103. Retrieved from https://doi.org/10.54784/1990-6587.1196

This article is brought to you by iRepository for open access under the Creative Commons Attribution 4.0 License and is available at https://ir.iba.edu.pk/businessreview/vol6/iss2/8. For more information, please contact irepository@iba.edu.pk. 


\title{
DISCUSSION
}

\section{Financial Development And Firms' Growth In Textile Industry Of Pakistan: A Panel Data Analysis}

\author{
Ijaz Hus sain \\ Beaconhouse National University, Lahore, Pakistan
}

\begin{abstract}
This discussion uses secondary data from "Balance Sheet Analys is (20002009) of Joint Stock Companies Listed on the Karachi Stock Exchange published by Statistics Department of State Bank Of Pakistan" and covers a panel of 75 textile firms of textile industry in Pakistan.

Findings of this study indicate that all explanatory variables included in our model have significant influence on firms' growth. Lagged profitability and efficiency and financial development have statistically significant and positive impact on firms' growth while financial leverage, size, risk, real cost of debt, energy crisis and abolishment of textile quota have negative impact. Acute energy crisis starting from 2007 has severely hit the growth of textile sector. Removal of textile quota from 2005 onwards has also negative impact on firms' growth.

The signs and impact of the last two explanatory variables help us in understanding why the investment and growth process stimulated though financial development and liberalization could not be sustained. Firms with squeezed operations on account of load shedding of electricity, load management of gas and reduced foreign demand on account of abolishment of textile quota and trapped in high levels of debt and associated fixed financial costs are now bearing the consequences of high gearing. The refore, we suggest that long term interest bearing debt should be rescheduled and restructured to relieve the firms from the debt trap; energy crisis must be resolved on war footings and intensive efforts should be made to explore new foreign markets
\end{abstract}

JEL Classification: M00, M20, O00

Key words: Firms' growth, financial development, financial liberalization, panel data analysis

Non-financial corporate sector (private and public enterprises) along with financial sector plays critical role in vibrant economic growth of a country because it produces goods and services for local as well as foreign markets, creates job opportunities, and contributes to government's tax revenue to finance its public expenditure on economic social infrastructure, sometimes contributes to foreign exchange reserves also, becomes a part of forward and backward linkages of the value chain.

Author is in particular thankful to Dr. Hafiz A Pasha, Dean, School of Social Sciences, Beaconhouse National University, Lahore, for his valuable guidance and advice. 
There exists evidence of substantial expansion in the banking system, $i$ mprovement in the equity market and financial liberalization during Musharraf era followed by high growth periods till 2007 (Figure 2). Real interest rate remained extremely low in particular in early part of last decade till they reached to negative level in 2005. Financial development and easy credit policies gave boost to the peak levels of gearing ratios for textile sector as well as overall industry (Figure 1). This provides an evidence of the impact of financial liberalization.

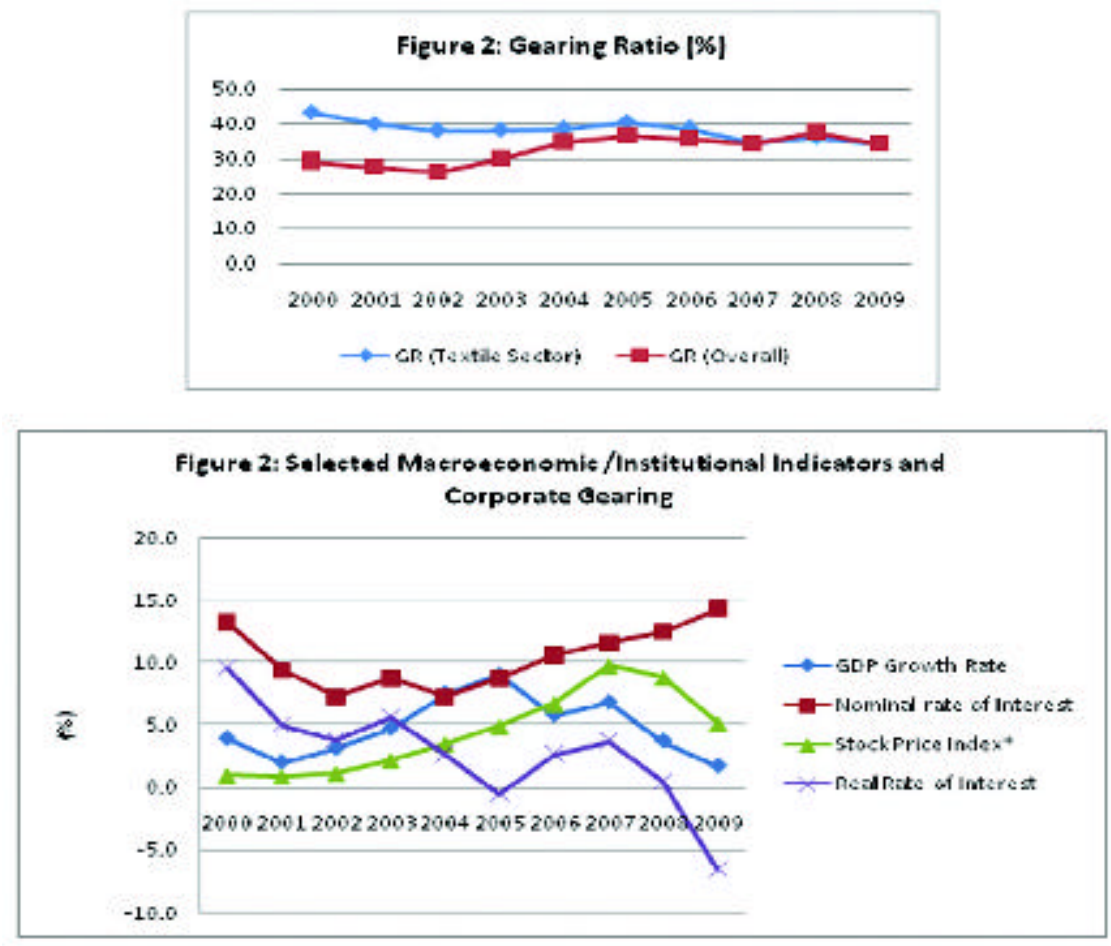

*Karachi General Index divided by 1000.

Source: Balance Sheet Analysis of Non-Financial Companies Listed in Karachi Stock exchange of Pakistan (Various issues), Hand Book on Statistics of Pakistan (2010), State Bank of Pakistan

These facts raise a few interesting and important questions in this regard: (i). What are key drivers for firms' growth for non-financial corporate sector? (ii). Can financial Development and liberalization stimulate investment and growth in non-financial corporate sector? (iii). Can such growth of firms be sustainable? (iv). The question of causality between growth of non-financial corporate and financial sector can also be explored. This paper examines the impact of financial development and liberalization for firms' growth among other growth drivers for a panel of 75 firms of textile industry in Pakistan and partially explores the question of growth sustainability.

This paper is structured as follows: Section I reviews literature. Section II identifies data sources, variables and rese arch methodology. Section III focuses on findings and 
Section IV concludes the paper and presents policy implications.

\section{Literature review}

Gibrat's (1931) law states growth is proportional to size of the firms. Findings in Hart and Prais (1956), Simon and Bonini, 1958), Hymer and Pashigan (1962) support this view. Mansfield (1962), Due Reitz (1975), Hall (1987), Mata (1994), negate Gibrat's law and note that growth and size of the firms are negatively correlated while Singh and Whittington (1975) find growth and size to be positively related. Evans (1987), Audretsch (1995), Dunne and Hughes (1994) and Liu et al. (1999) report negative relationships between the growth, age, and size. Almas Heshmati (2001) define growth rate in terms of the number of employees, sales and assets and show that the relationship between the growth, size and age of firms is very sensitive with respect to the method of estimation, functional form and definition of growth and size. Butters and Linter (1945) report that most the small firms face difficulties in raising finance from capital market and exclusively use retained earnings to finance their growth process. Brealey and Myers (2000) note that almost $90 \%$ of the total investment by nonfinancial US companies is financed through internally generated funds during 1990s. Robert E. Carpenter and Bruce C. Petersen (2002) test a panel of more than 1600 small firms and identify that growth of the firms is constrained by their internal finance. Leonardo Becchetti and Giovanni Trovato (2001) identify that small and medium sized firms' growth in Italy is significantly affected by size, age, export capacity and cre dit rationing.

Literature also documents some other determinants of firms' growth including research and development (Hall, 1987), ownership structure (Variyam and Krybill, 1992), financial leverage (Lang et al., 1996), human capital and exports (Liu et al., 1999).

Mohsin S. Khan and Carmen M. Reinhart (2002) present a growth model that separates the effects of public sector and private sector investment. This model is estimated for a cross-section sample of 24 developing countries, and the results show that private investment has a larger direct effect on growth than that of public investment. Jose De Gregorio and Pablo E. Guidotti (2000) examine the empirical relationship between longrun growth and proxy of ratio between bank credit to the private sector and GDP for financial development, and find that this proxy is positively correlated with growth in a large crosscountry sample. This motivates us to include a proxy for financial development as one of the potential growth driver for firms in our model.

\section{Data and research methodology}

\section{Sample set}

This paper uses secondary data from "Balance Sheet Analysis (2000-2009) of Joint Stock Companies Listed on the Karachi Stock Exchange published by Statistics Department of State Bank Of Pakistan." The sample of this study covers all 75 firms of textile industry with complete and consistent 10 years data series. This paper excludes the firms with incomplete and inconsistent data series. The firms with negative equity are also excluded.

Summary of the statistics is presented in Annexure A-1. Correlation coefficients are presented in Annexure A-2 to rile out multi-co-linearity between the regressors. There is some evidence of multi-co-linearity between the dummy for removal of textile quota and financial development. Table 1 below presents the proxies for dependent and explanatory variables: 
Table 1: List, Definitions and Symbols of Proxy Variables

\begin{tabular}{ll}
\hline \multicolumn{1}{c}{ Variable } & \multicolumn{1}{c}{ Symbol and Definition } \\
\hline $\begin{array}{l}\text { Dependent Variable: } \\
\text { 1. Growth }\end{array}$ & $\begin{array}{l}\mathrm{G}=\mathrm{d}(\log (\mathrm{ta}): \text { First difference of logarithm of the book } \\
\text { value of total assets }\end{array}$ \\
& \\
Explanatory Variables: & $\begin{array}{l}\text { ROA: Return on Assets=Net Profit Margin x Asset Turn } \\
\text { Over }\end{array}$
\end{tabular}

2. Profitability and Efficiency

$=$ Net profit after tax divided by net sales $\mathrm{x}$ Sales divided by Total Assets

3. Financial Leverage

4. Size

5. Risk

6. Real cost of Debt

7. Financial Development

8. Energy Crisis

9. Textile Quota
DER: Debt-Equity Ratio: Book value of total liabilities divided by book value of total assets.

GS: Gross Sales

$\mathrm{EV}=$ Earnings Volatility $=$ Squared deviation of 10 years net profit margin from the mean

$\mathrm{R}=\mathrm{Real}$ rate of interest

FD: Sum of market capitalization and banking credit divided by GDP

$\mathrm{DEC}=$ Dummy Variable for energy crisis $=1$ for the year with energy crisis and zero otherwise

$\mathrm{DQ}=$ Dummy variable for abolishment of textile quota $=1$ for the years in absence of textile quota and zero otherwise

In view of on literature review in previous section and availability of data, general form of our firms' growth model is as follows:

Firms' Growth = F (Profitability and Efficiency, Financial Leverage, Size, Risk, Real Cost Of Debt, Financial Development, Energy Crisis, Textile Quota)

This study uses highly popular statistical model of panel data analysis that combines cross section and time series data and estimates pooled regression of a standard model in the following form:

$$
G_{i t}=\beta_{0+} \beta_{1} X_{i t}+\beta_{2} Z_{t}+\varepsilon_{i t}
$$

Where $G$ denotes growth and subscript i specifies cross section dimension (firms) and $\mathrm{t}$ specifies time dimension of the data set. $\beta_{0}, \beta_{2}$ and $\beta_{2}$ are unknown constants. $X_{\text {it }}$ 
represents the set of firm-specific explanatory variables for firms which vary across firms as well as over time. $\mathrm{Z}_{\mathrm{t}}$ is the set of macroeconomic or institutional explanatory variables that vary over time only. $\varepsilon_{i t}$ is composite error term comprising of firm-specific component, time-specific component $\mu_{i}$, and a component $\boldsymbol{x}_{i}$ varying over time and across firms $w_{i t}$.

Depending on the structure of the error term and nature of its correlation with explanatory variables, there are several ways to estimate our growth model. Ordinary Least Squares is appropriate choice if no unobservable firm- and time-specific factors exist. But in fact, both firm-and time-specific unobservable effects may exist in practice. Choice of random effect model is appropriate when unobservable effects are included in error term and variance-covariance matrix of non-spherical errors is transformed to have consistent estimates of the standard errors. But random effect estimator becomes inconsistent when unobservable effects included in the error term are correlated with some or all regressors. Though relatively inefficient, an alternative choice is fixed effect model which provides consistent estimates regardless of the fore-mentioned correlation.

\section{Findings}

First we test the evidence of cross section and period effects and then we identify whether they are correlated with the regressors. Our tests show that there is strong evidence of period and cross section random and fixed effects. We use fixed effect specification which includes the variables that vary across firms and over time, cross section and period dummy variables. We test joint significance of the cross section and period dummy variables. Our results reveal that both cross-section and period fixed effects are significant at $1 \%$ level (Annexure 3-A). We also estimate random effect model and Hausman (1978) test rejects the exogeniety in the random effects model and the variance between the coefficients of random and fixed effect model is non-zero which restricts us to rely on fixed effect model. We present results of cross section fixed effects model below in Table 2.

Table 2: Regression Results

Dependent Variable: D(LOG(TA))

Method: Panel EGLS (Cross-section weights)

Sample (adjusted): 20012009

Periods included: 9

Cross-sections included: 75

Total panel (balanced) observations: 675

Linear estimation after one-s tep weighting matrix

White diagonal standard errors \& covariance (no d.f. correction)

\begin{tabular}{lcccc}
\hline \multicolumn{1}{c}{ Variable } & Coefficient & Std. Error & t-Statistic & Prob. \\
\hline C & 0.162436 & 0.017819 & 9.11580 & .00000 \\
ROA(-1): Lagged Profitability & & & & \\
and Efficiency & 0.001578 & 0.000565 & 2.79094 & 0.00540 \\
& & & & \\
DER: Financial Leverage & -0.000017 & 0.000005 & -3.81688 & 0.00010 \\
GS: Size & -0.000021 & 0.000006 & -3.82958 & 0.00010 \\
EV: Risk & -0.000001 & 0.000000 & -4.77181 & 0.00000
\end{tabular}


R: Real Cost of Debt

FD: Financial Development

DEC: Dummy Variable

for energy crisis

DQ: Dummy variable for abolishment of textile quota

$\begin{array}{llll}-0.009977 & 0.003169 & -3.14784 & 0.00170 \\ 0.002523 & 0.000507 & 4.97584 & 0.00000 \\ -0.119150 & 0.020372 & -5.84865 & 0.00000 \\ -0.119724 & 0.031928 & -3.74980 & 0.00020\end{array}$

Effects Specification

Cross-section fixed (dummy variables)

\begin{tabular}{lc}
\hline & Weighted Statistics \\
\hline R-squared & 0.292129 \\
Adjusted R-squared & 0.194079 \\
Durbin-Watson stat & 2.393622 \\
\hline & Unweighted Statistics \\
\hline R-squared & 0.175264 \\
Durbin-Watson stat & 2.393125 \\
\hline
\end{tabular}

Positive sign with return on as sets (profitability and efficiency) indicates that past higher profits and efficiency facilitate growth process by providing internal finance respectively. Debt accompanies periodic fixed interest payments which in turn reduce profitability of the firms thus limits internal sources of finance for growth. Therefore financial leverage has negative impact on growth. This also conforms to the view that most of firms are constrained by internal finance. Growth is negatively correlated with size. This finding contradicts the Gibrat's (1931) law which states that growth is proportional to the size of the firms regardless of the initial size.

Firms with relatively higher variability of profits and cash flows are deprived from internal finance as well as external finance because riskier firms will have unfavorable terms of credit, poor access to both credit market and equity market. This limits growth process of the firms. Higher cost of debt or external finance also hampers growth process though limiting external finance for firms; therefore, we find a negative sign with the real cost of debt.

Financial development is proxy for access to banks and equity market. Improvement in equity market exhibits relatively better macroeconomic environment and favorable expectations of investors and thus provides easy, cheaper and better opportunities to the firms for raising equity finance. Development of credit market relieves the firms from the constraint of external finance; therefore; financial development is positively related to growth. Statistically significant inverse relationship of real cost of debt and growth proves and highlights the fact that financial liberalization can motivate investment and firms' growth. Financial development is the second among the most significant explanatory variables with t-statistic 4.98 and p-value zero. Highly significant and positive sign with financial development provides us a strong evidence of the impact of financial development on firms' growth. As indicated by our results energy crisis is the most significant variable 
with t-statistic of 5.85 and p-value of zero among explanatory variable for firms' growth. Acute energy crisis starting from 2007 has severely hit the growth of textile sector. Abolishment of textile quota from 2005 onwards has also negative impact on firms' growth.

\section{Conclusion and policy implication}

Findings of this study indicate that all explanatory variables included in our model influence firms' growth. Lagged profitability and efficiency and financial development have statistically significant and positive impact on firms' growth while financial leverage, size, risk, real cost of debt, energy crisis and abolishment of textile quota have negative impact. Acute energy crisis starting from 2007 has severely hit the growth of textile sector. Abolishment of textile quota from 2005 onwards has also negative impact on firms' growth.

The signs and impact of the last two explanatory variables help us in understanding why the investment and growth process stimulated though financial development and liberalization could not be sustained. Firms with squeezed operations on account of load shedding of electricity, load management of gas and reduced foreign demand and trapped in high levels of debt and associated fixed financial costs are now bearing the consequences of high gearing. Therefore, we suggest that long term interest bearing debt should be rescheduled and restructured to relieve the firms from the debt trap; energy crisis must be resolved on war footings and intensive efforts should be made to explore new foreign markets.

\section{References}

Audretsch, D. B. (1995), “Innovation and Industry Evolution”. Cambridge: MIT Press.

Audretsch, D. B. (1995), "Innovation Growth and Survival”. International Journal of Industrial Organization 13, 441-447.

Brealey, Richard A., and Stewart C. Meyers (2000), "Principles of Corporate Finance, 6t ed". Boston: IrwinM cGraw-Hill, 2000.

Butters, J. Keith, and John Lintner (1945), "Effect of Federal Taxes on Growing Enterprises". Boston: Harvard University, 1945.

Du Reitz, G. (1975), "New Firm Entry in Swedish Manufacturing Industries during the Post-War Period". Doctoral Dissertation, Stockholm.

Dunne, T. and A. Hughes (1994), "Age, Size, Growth and Survival: U.K. Companies in the 1980s". Journal of Industrial Economics 42, 115-140.

Evans David S., (1987), "The Relationship between Forms Growth, Size and Age: Estimates for 100 Manufacturing Industries." The Journal of Industrial Economics. Volume 35. No. 4, The Empirical Renaissance in Industrial Economics (June, 1987), pp. 567-581.

Evans, D. S. (1987), 'Tests of Alternative Theories of Firm Growth". Journal of Political Economy 95, 657-674.

Evans, D. S. (1987), 'The Relationship between Firm Growth, Size and Age: Estimates for 100 Manufacturing Industries”. Journal of Industrial Economics 35, 567-581. 
Gibrat, R. (1931), “On Economic Inequality” (Paris, France: Recueil Sirey Bookstore).

Hall, B. H. (1987), “The Relationship between Firm Size and Firm Growth in U.S. Manufacturing Sector". Journal of Industrial Economics 35, 583-606.

Hart, P. E. and S. J. Prais (1956), "The Analysis of Business Concentration: A Statistical Approach". Journal of the Royal Statistical Society Series A, 150-191.

Hausman, J.A. (1978), "Specification Tests in Econometrics", Econometrica, 46,1251-1271.

Jose De Gregorio and Pablo E. Guidotti (2000), "Financial development and economic growth" International Monetary Fund, Washington DC, U.S.A. Available at:

Lang, L., E. Ofek and R. M. Stulz (1996), "Leverage, Investment, and Firm Growth". Journal of Financial Economics 40, 3-29.

Liu, J.-T., M.-W. Tsou and J. Hammitt (1999), "Do Small Plants Grow Faster? Evidence from the Taiwan Electronics Industry". Economics Letters 65, 121-129.

Mansfield, E. (1962), "Entry, Gibrat's Law, Innovation, and the Growth of Firms". American Economic Review 52, 1023-1051.

Mata, J. (1994), "Firm Growth during Infancy". Small Business Economics 6, 27-39. Meyer, L. H. (1998), "The Present and Future Roles of Banks in Small Business Finance". Journal of Banking and Finance 22, 1109-1116.

Mohsin S. Khan and Carmen M. Reinhart (2002), "Private investment and economic growth in developing countries". International Monetary Fund, Washington, DC, USA. Available at: .

Robert E. Carpenter and Bruce C. Petersen (2002), "Is the Growth of Small Firms Constrained by Internal Finance?" The Review of Economics and Statistics, Vol. 84, No. 2 (May, 2002), pp. 298-309 Published by: The MIT Press. URL: http://www.jstor.org/stable/3211778.

Singh, A. and G. Whittington (1975), “The Size Distribution of Business Firms”. American Economic Review 48, 607-617.

State Bank of Bank of Pakistan (2000-2009), "Balance Sheet Analysis of Joint Stock Companies Listed on the Karachi Stock Exchange Volume II" (2000-2009), Statistics and Data Warehouse Department. State Bank of Bank of Pakistan.

State Bank of Pakistan (2010), "Handbook of Statistics on Pakistan Economy”, (2010), Statistics and Data Warehouse Department. State Bank of Pakistan.

Variyam, J. N. and D. S. Kraybill (1992), "Empirical Evidence on Determinants of Firm Growth". Economics Letters 38, 31- 36. 
Anexure A

A-1: Summary Statistics

\begin{tabular}{|c|c|c|c|c|c|c|c|c|c|}
\hline $\mathbf{D}(\mathbf{L}$ & OG(TA)) & ) $\operatorname{ROA}(-1)$ & ) DER & GS & EV & $\mathbf{R}$ & FD & DEC & DQ \\
\hline Mean & 0.12 & 3.81 & 306.43 & 2328.39 & 740.03 & 1.91 & 46.99 & 0.22 & 0.56 \\
\hline Median & 0.09 & 2.60 & 203.20 & 1284.50 & 5.90 & 2.70 & 49.90 & 0.00 & 1.00 \\
\hline Maximum & 1.17 & 77.60 & 23245.70 & 23870.30 & 415586.50 & 5.70 & 87.04 & 1.00 & 1.00 \\
\hline Minimum & $-1.35-$ & -187.70 & 0.00 & 4.20 & 0.0 & -6.50 & 10.81 & 0.00 & 0.00 \\
\hline Observations & 675 & 675 & 675 & 675 & 675 & 675 & 675 & 675 & 675 \\
\hline
\end{tabular}

A-2: Correlation Coefficients

\begin{tabular}{lrrrrrrrrr}
\hline & D(LOG(TA) $)$ & ROA(-1) & DER & GS & EV & R & FD & DEC & DQ \\
\hline D(LOG(TA) $)$ & 1 & 0.126 & -0.094 & 0.066 & -0.032 & 0.133 & -0.042 & -0.185 & -0.079 \\
ROA(-1) & 0.126 & 1 & -0.053 & 0.027 & 0.020 & 0.169 & -0.192 & -0.174 & -0.186 \\
DER & -0.094 & -0.053 & 1 & -0.040 & -0.011 & -0.047 & 0.061 & 0.016 & 0.075 \\
GS & 0.066 & 0.027 & -0.040 & 1 & -0.026 & -0.157 & 0.175 & 0.178 & 0.167 \\
EV & -0.032 & 0.020 & -0.011 & -0.026 & 1 & 0.020 & -0.049 & -0.019 & -0.043 \\
R & 0.133 & 0.169 & -0.047 & -0.157 & 0.020 & 1 & -0.353 & -0.748 & -0.609 \\
FD & -0.042 & -0.192 & 0.061 & 0.175 & -0.049 & -0.353 & 1 & 0.420 & 0.862 \\
DEC & -0.185 & -0.174 & 0.016 & 0.178 & -0.019 & -0.748 & 0.420 & 1 & 0.478 \\
DQ & -0.079 & -0.186 & 0.075 & 0.167 & -0.043 & -0.609 & 0.862 & 0.478 & 1 \\
\hline
\end{tabular}

A-3: Redundant Fixed Effects Tests

Test cross-section fixed effects

\begin{tabular}{lccc}
\hline Effects Test & Statistic & d.f. & Prob. \\
\hline Cross-section F & 1.327399 & $(99,788)$ & 0.0235 \\
Cross-section Chi-square & 138.813135 & 99 & 0.0051 \\
Period F & 6.657029 & $(8,788)$ & 0.0000 \\
Period Chi-square & 58.858375 & 8 & 0.0000 \\
Cross-Section/Period F & 1.762618 & $(107,788)$ & 0.0000 \\
Cross-Section/Period Chi-square & 193.121273 & 107 & 0.0000 \\
\hline
\end{tabular}

Hegel wrote that no one is a hero to his valet, no because he isn't a hero, but because the valet is a valet.

Conrad Black 